\title{
Effect of marine feed addition on growth of poultry
}

\author{
Zoya Tsoy $^{1, *}$, Yuri Nikulin ${ }^{1}$, and Olga Nikulina $^{1}$ \\ ${ }^{1}$ Primorsky State Agricultural Academy, 692525, 44, Blukhera prospect, Ussuriisk, Russia
}

\begin{abstract}
Poultry farming is one of the most precocious and important branches of animal husbandry. It makes it possible to get food products such as meat and eggs in the shortest time. The main factor affecting the development of poultry farming is the feed base. For poultry, the lack of protein and minerals is very harmful. Far East has all the opportunities to realize its genetic potential. Primorye region makes it possible to widely use inexpensive seafood and waste products, as well as plant raw materials in animal and poultry feeding. Marine and fish products, as well as waste from their reprocessing, are rich in protein and minerals necessary to ensure the fullness of animal and poultry rations. Additions of marine origin have antioxidant, radioprotective activity, increase the body's resistance to diseases, increase the immune system, and improve metabolism.
\end{abstract}

\section{Introduction}

One of the main factors that hinder the development of animal husbandry and poultry farming is the lack of food supplement and the inferiority of manufactured feed. At the same time, one of the main problem in many countries is a deficit in the feed balance of protein and minerals. The efforts of scientists and specialists are aimed at finding ways to meet the needs of poultry in nutrients by increasing the production and rational using of traditional and non-traditional feed and balancing feed additives. For poultry, the deficiency of protein and minerals is very harmful.

Marine products, seafood and fish products, as well as waste from their processing and reprocessing, are rich in protein and minerals necessary to ensure the fullness of animal and poultry diets. Feeds and feed additions of marine origin have antioxidant, radioprotective activity, increase the body's resistance to diseases, increase the immune system of animals and poultry, improve metabolism.

In the far Eastern region, there is an opportunity to expand the use of the species diversity of extracted bioresources and their waste from processing in the feeding of farm animals and particularly poultry.

The Far East region has all the possibilities for realizing the genetic potential of farm animals and poultry. In Primorsky region it is possible to use inexpensive seafood and waste products from their processing in feeding animals and poultry widely.

* Corresponding author: zoyatsoy84@mail.ru 
Fish meal made from non-food fish and waste from processing of food fish, crustaceans and marine mammals and other hydrobionts is the most valuable source of protein and amino acids. It is used for the enrichment of compound feeds and for maintaining the correct balance of fatty acid and amino acid compositions, the content of raw protein, the level of calcium and phosphorus, as well as for the prevention of diseases of poultry. Fishmeal contributes to the development of vital body systems: the immune system is activated, growth of young poultry, egg production increases, the digestibility of nutrients increases, and young birds fledge better. [9-11]

Fish meal is the most valuable component of compound feeds in terms of its nutritional characteristics. It contains at least $50 \%$ of raw protein, rich in all the main amino acidslysine, methionine, threonine, tryptophan, etc. In addition to protein, the product contains calcium, phosphorus, and unsaturated fatty acids with an optimal ratio of omega-6 to omega-3. It is very important that the digestibility of the main nutrients of fishmeal is significantly higher than the digestibility of the same substances in most plant-based feeds; the digestibility of fishmeal reaches $92 \%$. Fish meal contains a wide range of natural substances and minerals, such as phosphorus (almost all seafood is rich in it), as well as calcium, a whole set of amino acids, iodine, selenium, as well as vitamins A, D and group $\mathrm{B}$ each of these elements has its own useful properties.

Shrimp meal is used as a complete protein for the production of feed in poultry and nonproductive animals. It is well combined with fishmeal.

Shrimp meal is added as bait for animals and birds, as well as in fishing boilies, mastic and dough.

Daily addition of additives to feed contributes to:

reduce the cost of products enriched with vitamins and minerals,

increase the immune system of the animal,

rapid growth and assimilation,

improve fertility and egg production (for productive animals, birds, fish).

Shrimps contain many useful substances: vitamins C, B9, B1, B2, A, D, PP, E and Bcarotene. Trace elements: iron, sodium, potassium, iodine, phosphorus, sulfur, zinc, calcium, manganese, fluorine, magnesium, cobalt, molybdenum and copper. shrimps contain a lot of iodine, which is necessary for the proper functioning of the thyroid and endocrine system as a whole. Calcium, which is needed to strengthen bone and muscle, normalize the kidneys and immune system, and improve blood formation. Shrimp flour is also rich in potassium.

The Corbicula contains a full-fledged protein, glycine, taurine and other equally important amino acids. Shellfish is also rich in vitamins a, B, E, D, potassium, selenium, nicotinic and ascorbic acids.

Corbicula increases the body's resistance to diseases.

Feed additive is prepared by mixing all components of raw materials, drying and grinding. The technology of preparation of feed additives is quite simple and does not require the use of special equipment and significant energy costs, which makes the cost of feed affordable. [12-16]

Since the Far East is rich in marine hydrobionts, this makes it possible to introduce feed flour from fish and marine waste as a biological additive in the composition of mixed feeds for agricultural poultry. The use of the claimed additive will help eliminate the deficit of protein, vitamins and minerals by replacing expensive vitamin and mineral premixes with cheaper waste from fish and marine production.

We conducted a scientific research experiment to include a feed concentrate (addition) of marine origin in the diet of young poultry. The experiments were carried out in the farm of the Ussuriisky district of Primorsky region on the hens of the Haysex White cross. 
The purpose of the research is to study the efficiency of including a feed concentrate of marine origin in the diets of young poultry.

To achieve this aim, we have formulated the following tasks:

1. To detect the optimal feeding doses in the diets of young poultry

2. To study influence of including a feed concentrate on the poultry growth

3. To compare the economic effect of using feed addition in the diets of control and experimental groups.

\section{Research methods}

We formed 4 groups of chickens at the age of 5 weeks with 150 heads by means the method of analogs (control and three experimental ones) to study the effect of marine feed addition. All livestock were kept in the same conditions, optimal for temperature, lighting, and ventilation. The control group received the main diet adopted in the farm. The experimental group with the main diet received a feed additive in the form of flour from waste processing of Japanese Corbicula, shrimp and fish. The research scheme is shown in table 1.

Table 1. Research scheme

\begin{tabular}{|l|l|l|l|l|}
\hline $\begin{array}{l}\text { Feed } \\
\text { complex }\end{array}$ & Group & Length of research & $\begin{array}{l}\text { Amount of } \\
\text { poultry }\end{array}$ & Diet \\
\hline \multirow{2}{*}{$\begin{array}{l}\text { Marine feed } \\
\text { meal }\end{array}$} & control & 90 days & 150 & $\mathrm{BR}$ \\
\cline { 2 - 5 } & I experimental & 90 days & 150 & $\mathrm{BR}+3 \%$ \\
\cline { 2 - 5 } & II experimental & 90 days & 150 & $\mathrm{BR}+5 \%$ \\
\cline { 2 - 5 } & III experimental & 90 days & 150 & $\mathrm{BR}+7 \%$ \\
\hline
\end{tabular}

*BR - Basic ration (diet)

We entered the following doses of marine feed meal in the diet of poultry: 3, 5 and $7 \%$ in the ration. The control group was fed a diet adopted by the farm, the experimental groups received basic ration plus feed flours according the scheme. Young poultry were kept in cell batteries during the experiment. The scientific research lasted 90 days (12 weeks), according to the methodology.

\section{Results}

The using of additions had a positive effect on the growth and development of experimental poultry.

The results of the research are presented in table 2 .

Table 2. Growth of young hens, $(\mathrm{X} \pm \mathrm{Sx}, \mathrm{n}=150)$

\begin{tabular}{|c|c|c|c|c|}
\hline \multirow[t]{2}{*}{ Index } & \multicolumn{4}{|c|}{ Group } \\
\hline & control & I experimental & II experimental & III experimental \\
\hline \multicolumn{5}{|c|}{ Marine feed meal } \\
\hline $\begin{array}{l}\text { Live weight at } \\
\text { the begging of } \\
\text { the research, g }\end{array}$ & $335,1 \pm 2,1$ & $334,9 \pm 2,14$ & $335,8 \pm 2,15$ & $335,1 \pm 2,30$ \\
\hline $\begin{array}{l}\text { Live weight at } \\
\text { the end of the } \\
\text { research, } \Gamma\end{array}$ & $1110,4 \pm 4,07$ & $1128,5 \pm 5,01 * *$ & $1143,5 \pm 4,28^{* *}$ & $1161,9 \pm 5,02 * *$ \\
\hline $\begin{array}{l}\text { Absolute } \\
\text { increase } \\
\text { gain, g }\end{array}$ & 775,3 & 793,6 & 807,7 & 826,8 \\
\hline Daily gain, $g$ & 8,61 & 8,82 & 8,97 & 9,2 \\
\hline Safety, \% & 96,8 & 97,1 & 98,0 & 98,5 \\
\hline
\end{tabular}


Where: $* * * \mathrm{P} \leq 0,1, * * \mathrm{P} \leq 0,01, * \mathrm{P} \leq 0,05$.

The using of marine feed meal in diets of young poultry had a positive effect on growth. In the experimental groups, the absolute and average daily gain were maximal in the III experimental group. The absolute increase of gain was 826.8 grams, and the average daily gain was 9.2 grams. Safety in experimental groups was higher than safety in control group on $0.3-1.7 \%$.

Also we studied development of experimental poultry. The main index of development is length of carcass. We took measurements, in particular the length of the carcass in age of 120 days. The results are shown in table 3.

Table 3. Length of carcass of experimental poultry, $\mathrm{mm}$

\begin{tabular}{|l|c|}
\hline Group & Marine feed meal \\
\hline control & 179.3 \\
\hline I experimental & 183.6 \\
\hline II experimental & 198.4 \\
\hline III experimental & 202.1 \\
\hline
\end{tabular}

The table shows that the highest index were in the experimental groups. The advantage of the experimental groups over the control when using marine feed meal was 4.3-22.8 $\mathrm{mm}$.

The superiority of experimental groups over control can be showed in more detail in figures 1 .

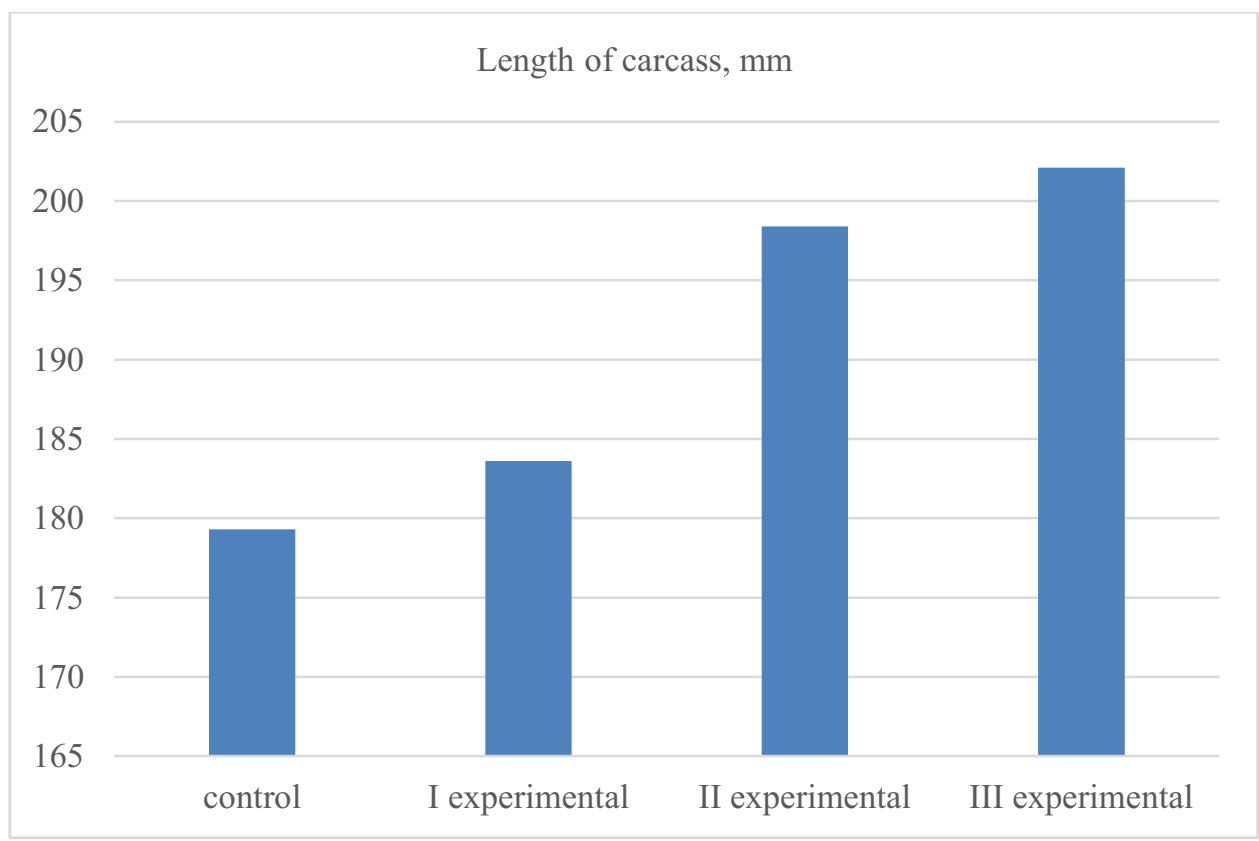

Fig. 1. Length of carcass.

Research experiments proved our hypothesis that marine feed complex help increase growth and development index. Meal from fish, shrimp and Japanese Corbicula has a positive effect on the growth and development of chickens. The research results are reliable and authenticity. During the experiment, all poultry were kept in the same conditions. By 
the end of research experiments poultry of experimental groups had the higher index than control group index.

Using marine feed meal absolute increase of gain was higher by 18.3-51.5 $\mathrm{g}$ than control and daily gain higher by0.21-0.59 g than control. The highest length of carcass was in III experimental group (200.1g).

Safety of poultry population also was insignificant higher in experimental groups. It amount to $96.8-98.5 \%$ in comparison with control $96.8 \%$

As for optimal doses of plant additions, we confirmed the doses maximum $10 \%$. Also growth of young poultry is to up $5 \%$.

Thus, using untraditional feed additions (marine feed) in feeding of poultry Haysex White has a positive effect on growth, gaining, safety and length of carcass.

To determine the economic effect of using a marine feed meal, we conducted a production experiment. The production experiment was carried out in the same farm, the number of poultry was 100 in each group, two groups were formed (control and experimental). The duration of the experiment is 90 days. The results are shown in table 4 .

Table 4. Economic results of marine feed meal inclusion.

\begin{tabular}{|l|c|c|}
\hline \multirow{2}{*}{\multicolumn{1}{|c|}{ Index }} & \multicolumn{2}{c|}{ Group } \\
\cline { 2 - 3 } & control & experimental \\
\hline Amount of poultry, heads. & 100 & 100 \\
\hline The duration of the experience, days & 90 & 90 \\
\hline Total gain, kg & 77.5 & 81.7 \\
\hline Price of 1 kg of chickens, RUB & 250 & 250 \\
\hline Profits from the sale of chickens, RUB & 19375 & 20425 \\
\hline Price of marine feed concentrate, RUB & - & 675 \\
\hline $\begin{array}{l}\text { Additional profit of the farm from the inclusion } \\
\text { of concentrate, RUB. }\end{array}$ & - & 1050 \\
\hline $\begin{array}{l}\text { Additional profit of the company from the } \\
\text { inclusion of additives, rubles }\end{array}$ & - & 375 \\
\hline
\end{tabular}

Economic efficiency of using marine feed meal is shown in figure 2.

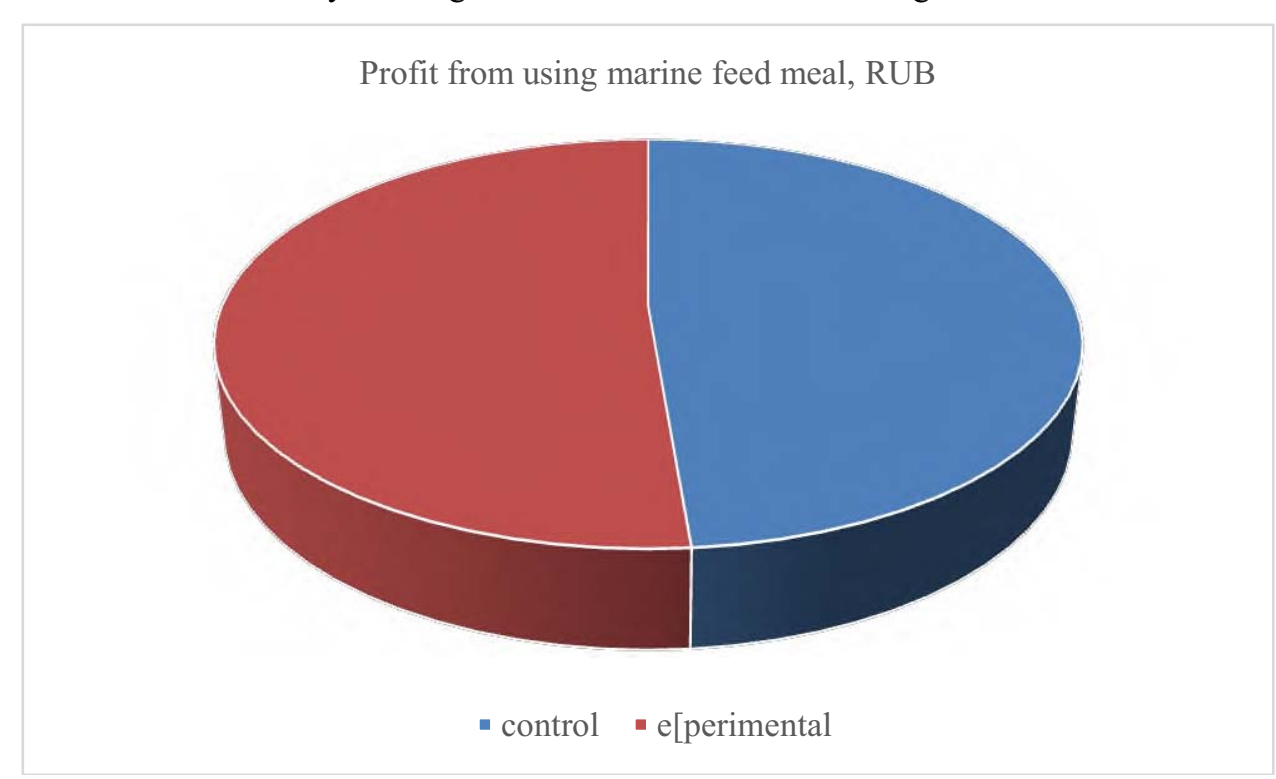

Fig. 2. Profits frm the sale of eggs, RUB. 
The production experiment proved that the marine feed meal has a positive effect on the growth and development index and economic indicators. When marine feed meal is included in the compound feed, the economic effect was higher on 375 rubles per 100 heads.

\section{References}

1. Z. Mehdipour, Poult. Sci, 8, 95-107 (2020) doi:10.22069/PSJ.2020.17615.1543

2. H. Habibi, Poultr. Sci Vol, 7(2), 141-150 (2019) doi:10.22069/PSJ.2019.16579.1447

3. M. Cahyadi, Poultr. Sci., 7(2), 179-184 (2019) doi:10.22069/PSJ.2019.15778.1371

4. R. Mirshekar, Poultr. Sci., 6(2), 119-127 (2018) doi: 10.22069/PSJ.2018.14712.1318

5. M. Sedghi, Poultr. Sci., 6(2), 129-137 (2018) doi:10.22069/PSJ.2020.17407.1528

6. S. I. Kononenko, 9 International Symposium of Animal Biology and Nutrition, 22 (2010)

7. G. Dibaibee, Poultr. Sci., 5(1), 7-15 (2017)

8. E. Pourtorabi, Poultr. Sci., 5(1), 17-27 (2017)

9. A. Aghaei, Poultr. Sci., 5(1), 57-64 (2017)

10. R. L. Sharvadze, EurAsian Journal of BioSciences Eurasia J Biosci, 12, 143-148 (2018)

11. H. Bazdidi, Poultr. Sci., 4(2), 89-95 (2016)

12. R. Majidzaden Heravi, Poultr. Sci., 4(2), 107-116 (2016)

13. M. Fathi, Poultr. Sci., 4(2), 139-146 (2016)

14. Z. V. Tsoy, CIS-Korea Conference of Science and Technology, 76-83 (2015)

15. Z. V. Tsoy, Global Journal of Biotechnology \& Biochemistry, 8(4), 74-77 (2013)

16. R. L. Sharvadze, EurAsian Journal of BioSciences Eurasia J Biosci., 1(12), 143-148 (2018) 